Original

\title{
DNA Adduct Formation, Nucleolar Segregation and Cell Proliferation in Rats Treated with 2-Amino-1-methyl-6- phenylimidazo $[4,5-b]$ pyridine
}

\author{
Takayoshi Imazawa ${ }^{1, \#}$, Akiyoshi Nishikawa ${ }^{1}$, Makoto Miyauchi ${ }^{1}$, Kazushi Okazaki ${ }^{1}$, \\ Satoru Takahashi ${ }^{2}$, Takashi Umemura ${ }^{1}$, and Masao Hirose ${ }^{1}$ \\ ${ }_{2}^{1}$ Division of Pathology, National Institute of Health Sciences, 1-18-1 Kamiyoga, Setagaya-ku, Tokyo 158-8501, Japan \\ ${ }^{2}$ Department of Experimental Pathology and Tumor Biology, Nagoya City University Graduate School of Medical \\ Sciences, 1 Kawasumi, Mizuho-cho, Mizuho-ku, Nagoya 467-8601, Japan \\ \# Present address: Toxicogenomics Project, National Institute of Biomedical Innovation, 7-6-8 Saito-Asagi, Ibaraki-city, \\ Osaka 567-0085, Japan
}

\begin{abstract}
In order to validate early biomarkers for chemical carcinogenesis, alterations of DNA damage and subsequent cell replication induced by 2-amino-1-methyl-6-phenylimidazo(4,5-b)pyridine (PhIP) were sequentially investigated in the rat colon and liver. Male 6-week-old Sprague Dawley rats were singly administered by gavage $300 \mathrm{mg} / \mathrm{kg}$ bw PhIP and control rats received vehicle alone. All rats were euthanized after 4-72 hr, and the organs were removed for histopathological examination, immunohistochemistry and electron microscopic observation. Immunohistochemically, in the colon, PhIP-DNA adduct already appeared at $4 \mathrm{hr}$ and the positive ratios peaked at $24 \mathrm{hr}$ after the PhIP exposure. Nucleolar alteration, demonstrable by electron microscopy as segregation of nucleolar components into granular and fibrillar compartments, was evident in cells of the target organ colon. Sequential observation clarified that such alteration was highest in frequency after $48 \mathrm{hr}$ in colon cells, suggesting that nucleolar segregation occurs subsequent to generation of DNA adduction. Following these events, Ki-67-labeling in the colon was significantly increased at $72 \mathrm{hr}$. No significant PhIP-DNA adduct formation, nucleolar alteration or cell proliferation were noted in colons of the control rats nor in livers regardless of the PhIP treatment. Our results thus indicate an identity between the target cells for PhIPDNA adduct formation, nucleolar segregation and enhanced cell replication, which correlated with DNA damage. These biomarkers could be useful for predicting the target organs of chemical carcinogenesis.

(J Toxicol Pathol 2007; 20: 39-47)
\end{abstract}

Key words: DNA adduct, nucleolar segregation, cell proliferation, PhIP, rat

\section{Introduction}

Heterocyclic amines (HCA) are widespread environmental genotoxic carcinogens found particularly after cooking procedures of ordinary meat and fish, and also in cigarette smoke ${ }^{1}$. It is generally accepted that covalent binding between an ultimate carcinogen and DNA is of prime importance in the early steps of tumor initiation ${ }^{2}$, and in fact HCA-DNA adducts have been demonstrated in human tissues ${ }^{3}$.

2-Amino-1-methyl-6-phenylimidazo(4,5-b)pyridine (PhIP) is the most prevalent food-derived $\mathrm{HCA}^{4}$ and has been shown to induce colon, mammary and prostate but not

Received: 19 October 2006, Accepted: 7 December 2006 Mailing address: Akiyoshi Nishikawa, Division of Pathology, Pathology, National Institute of Health Sciences, 1-18-1 Kamiyoga, Setagaya-ku, Tokyo 158-8501, Japan TEL: 81-3-3700-9819 FAX: 81-3-3700-1425

E-mail: nishikaw@nihs.go.jp liver cancers in rodents ${ }^{5-7}$. This compound undergoes metabolic activation in vivo and the resulting ultimate carcinogens ${ }^{8}$ bind to DNA to form $N$-(deoxyguanosin-8-yl)$\mathrm{PhIP}$ as a major adduct ${ }^{9}$. To examine the significance of DNA adduct formation in PhIP tumorigenesis, PhIP-DNA adducts in the target tissues were immunohistochemically assessed as described previously ${ }^{10}$. It has been reported that the immunohistochemical staining pattern of PhIP-DNA adducts differs according to anatomic location and cell type ${ }^{10}$. Namely, almost all organs including the colon, prostate and mammary gland were clearly positive, but not cells of the liver that is a non-target organ ${ }^{10}$.

In our previous study, DNA adduct formation was consistently demonstrated in the target cells of rats receiving a single intravenous injection of 4-hydroxyaminoquinoline 1-oxide (4HAQO) which is known as a powerful genotoxic carcinogen ${ }^{11}$. The target pancreatic acinar and cortical adrenal cells were clearly positive, but not the non-target liver cells ${ }^{11}$. Almost simultaneously or a little later, an 

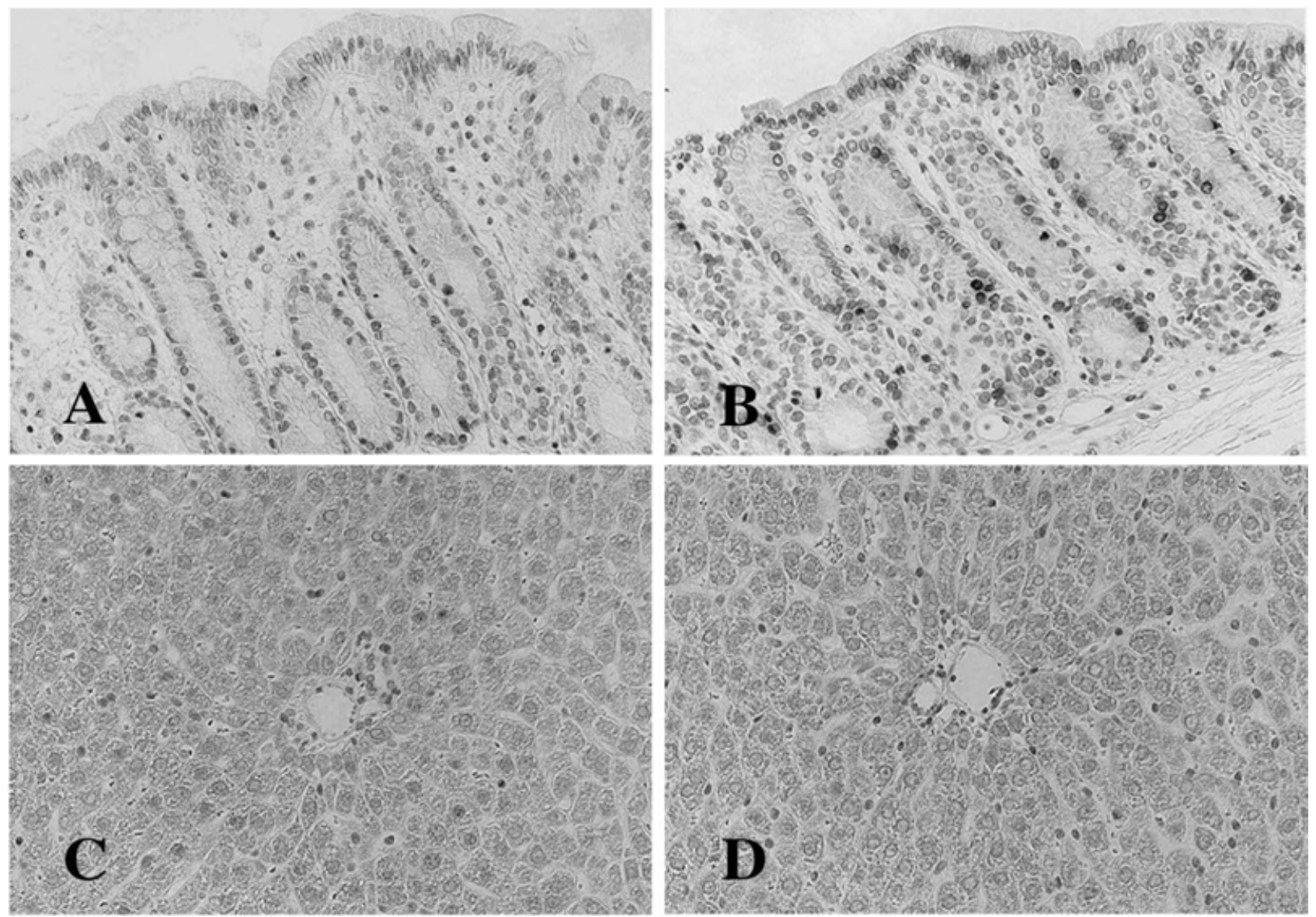

Fig. 1. Immunohistochemistry of PhIP-DNA adduct in the colon (A and B) and liver (C and D). (A) No evidence of immunoreactivity with PhIP-DNA adduct in colon epithelium cells of a control rat. (B) Immunoreactivity with PhIP-DNA adduct is evident in colon epithelium cells $24 \mathrm{hr}$ after treatment with PhIP. (C) No evidence of immunoreactivity with PhIP-DNA adduct in hepatocytes of a control rat. (D) Very few cells positive for PhIP-DNA adduct in hepatocytes $24 \mathrm{hr}$ after treatment with PhIP. Original magnification $\times 240$.

ultrastructural change called nucleolar segregation was noted in the target cells, suggesting a morphological marker for genotoxicity ${ }^{11}$. Thereafter, cell proliferation and apoptosis were increased in the target cells ${ }^{12}$.

The present study was conducted to concomitantly examine the induction of PhIP-DNA adduct formation, nucleolar alteration and cell proliferation in the tissues of rats given a single administration of PhIP. Proliferating cell nuclear antigen (PCNA) is closely involved in DNA replication and repair, in addition to increasing the efficiency of DNA synthesis ${ }^{13-18}$. Furthermore, to clarify changes in cell cycle/DNA replication of tissues the expression of proliferation-associated nuclear antigen Ki-67 was also evaluated because $\mathrm{Ki}-67$ reacts with a nuclear antigen which is present throughout the cell cycle $\left(\mathrm{G}_{1}, \mathrm{G}_{2}\right.$ and $\mathrm{M}$ phases) of proliferating cells, but is absent in quiescent $\left(\mathrm{G}_{0}\right)$ cells ${ }^{19,20}$. For comparison, the liver was selected as a non-target organ of PhIP carcinogenicity. In order to confirm ultrastructural changes such as nucleolar segregation, electron microscopical examination was also performed.

\section{Materials and Methods}

\section{Animals and chemical}

Male 6-week-old Sprague-Dawley rats (Charles River Inc., Atsugi, Japan), initially weighing approximately $160 \mathrm{~g}$, were used in this experiment. Rats were housed, 5 per wire cage, in an air-conditioned room maintained at $24 \pm 2^{\circ} \mathrm{C}$ and $55 \pm 5 \%$ relative humidity under a daily cycle of alternating 12-hr periods of light and darkness. The animals were given commercial standard diet (CRF-1: Oriental Yeast Inc., Tokyo, Japan) and tap water ad libitum. PhIP was purchased from Toronto Research Chemicals Inc. (Ontario, Canada).

\section{Experimental design}

The protocol for this study was approved by the Animal Care and Utilization Committee of the National Institute of Health Sciences. After a 1-week acclimatization period, 25 rats were given a single oral administration of PhIP dissolved in corn oil at a dose of $300 \mathrm{mg} / \mathrm{kg}$ body weight, while 25 control rats received a single administration of corn oil alone. Five rats from each group were sacrificed under 
ether anesthesia at 4, 6, 24, 48 and $72 \mathrm{hr}$ after PhIP or vehicle administration. At necropsy, samples of the colon and liver were immediately excised from each rat. The colon was investigated as a target organ of PhIP-toxicity and tumorigenicity, and the liver as a non-target organ.

\section{Electron microscopic examination}

Small specimens of all tissues were fixed in phosphatebuffered $2.5 \%$ glutaraldehyde for $2 \mathrm{hr}$ at $4^{\circ} \mathrm{C}$, post-fixed in phosphate-buffered $1.5 \%$ osmium tetroxide for $1 \mathrm{hr}$ at $4^{\circ} \mathrm{C}$, dehydrated in a series of alcohol concentrations and embedded in Epon 812. Ultrathin sections were stained with uranyl acetate and lead citrate, and examined under an electron microscope (JEM 100CXS, JEOL, Tokyo, Japan).

\section{Immunohistochemistry}

Tissue specimens were fixed in cold acetone at $4{ }^{\circ} \mathrm{C}$ over night or in $10 \%$ buffered formalin solution at room temperature for $24 \mathrm{hr}$, routinely processed, embedded in paraffin, cut at $4 \mu \mathrm{m}$ and stained with hematoxylin and eosin (H-E). For immunohistochemical staining, all tissues were heated by microwave in distilled water or by autoclave in citrate buffer for antigen retrieval ${ }^{20,21}$, and endogenous peroxidase was blocked by exposure to an aqueous solution of $1 \%$ peroxidic acid for $15 \mathrm{~min}$. Sections were then rinsed in phosphated-buffered saline (PBS; $\mathrm{pH} 7.2$ ), and examined with antibodies against each antigen using the avidin-biotin complex method (Vectastain ABC Elite kit; Vector Lab., Burlingame, CA). For assessing cell proliferative activity, anti-PCNA and anti-Ki67 mouse monoclonal antibodies (Dako Japan, Kyoto, Japan) were used on formalin-fixed tissues at dilutions of $1: 400$ and $1: 50$, respectively. Incubation with the primary antibody was performed at $4^{\circ} \mathrm{C}$ overnight. Binding was visualized by reaction of the enzyme complex with $0.05 \%$ 3,3'-diaminobenzidinetetrachloride (DAB; Dojindo Lab., Kumamoto, Japan) plus 0.01\% hydrogen peroxide in Tris-buffered saline containing $10 \mathrm{mM}$ sodium azide. The sections were subsequently counterstained with hematoxylin, dehydrated through a graded alcohol and xylene series, and mounted for microscopic examination. Immunohistochemical staining for PhIP-DNA adduct was carried out on acetone-fixed tissues according to the method described by Takahashi et al. ${ }^{10}$.

\section{Quantitative analysis and statistics}

For counting the numbers of cells positive for PhIPDNA adduct, PCNA and Ki67, approximately 500 cells were randomly selected from 4 different areas in each section and examined under a light microscope at a magnification of $x$ 400. For counting the numbers of cells exhibiting nucleolar segregation, electron microphotographs $(\times 8,000)$ were taken for samples of 30-60 randomly selected colon epithelium cells and hepatocytes. Data were statistically evaluated using the Student's $t$-test.

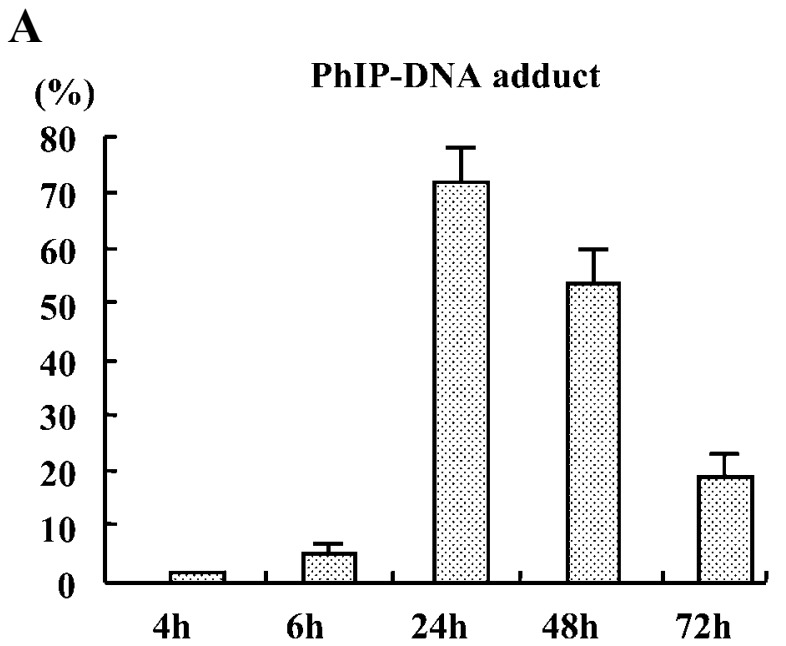

\section{B}

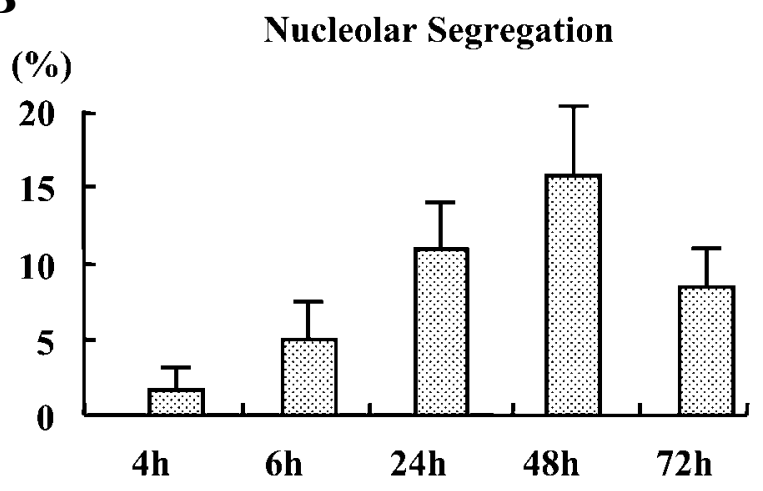

Fig. 2. Sequential changes in PhIP-DNA adduct formation (A) and nucleolar segregation $(\mathbf{B})$ in the colon of rats treated with PhIP. Data are mean \pm standard deviation values.

\section{Results}

\section{DNA adduct formation}

Representive immunohistochemical findings of PhIPDNA adduct formation are shown in Fig. 1. PhIP-DNA adduct formation was clearly detectable in nuclei of colon cells (Fig. 1B) after the PhIP-treatment, whereas in colon epithelial cells without carcinogen exposure the DNA adduct formation was not observed (Fig. 1A). In clear contrast, the non-target hepatocytes exhibited little or no positive stainability for DNA adducts throughout the experimental period regardless of PhIP treatment (Fig. 1C and 1D). The results of the sequential investigation of cells expressing PhIP-DNA adduct formation in response to PhIP are summarized in Fig. 2A. Stainability of PhIP-DNA adduct was already noted in colon epithelial cells $4 \mathrm{hr}$ after the PhIP treatment. Serial observation revealed a rapid increase in the number of PhIP-DNA adduct-positive epithelial cells with a peak of approximately $70 \% 24 \mathrm{hr}$ after the $\mathrm{PhIP}$ exposure in the colon, followed by a gradual decrease although appreciable numbers of the DNA adduct-positive cells still persisted even at $72 \mathrm{hr}$ after PhIP administration. 

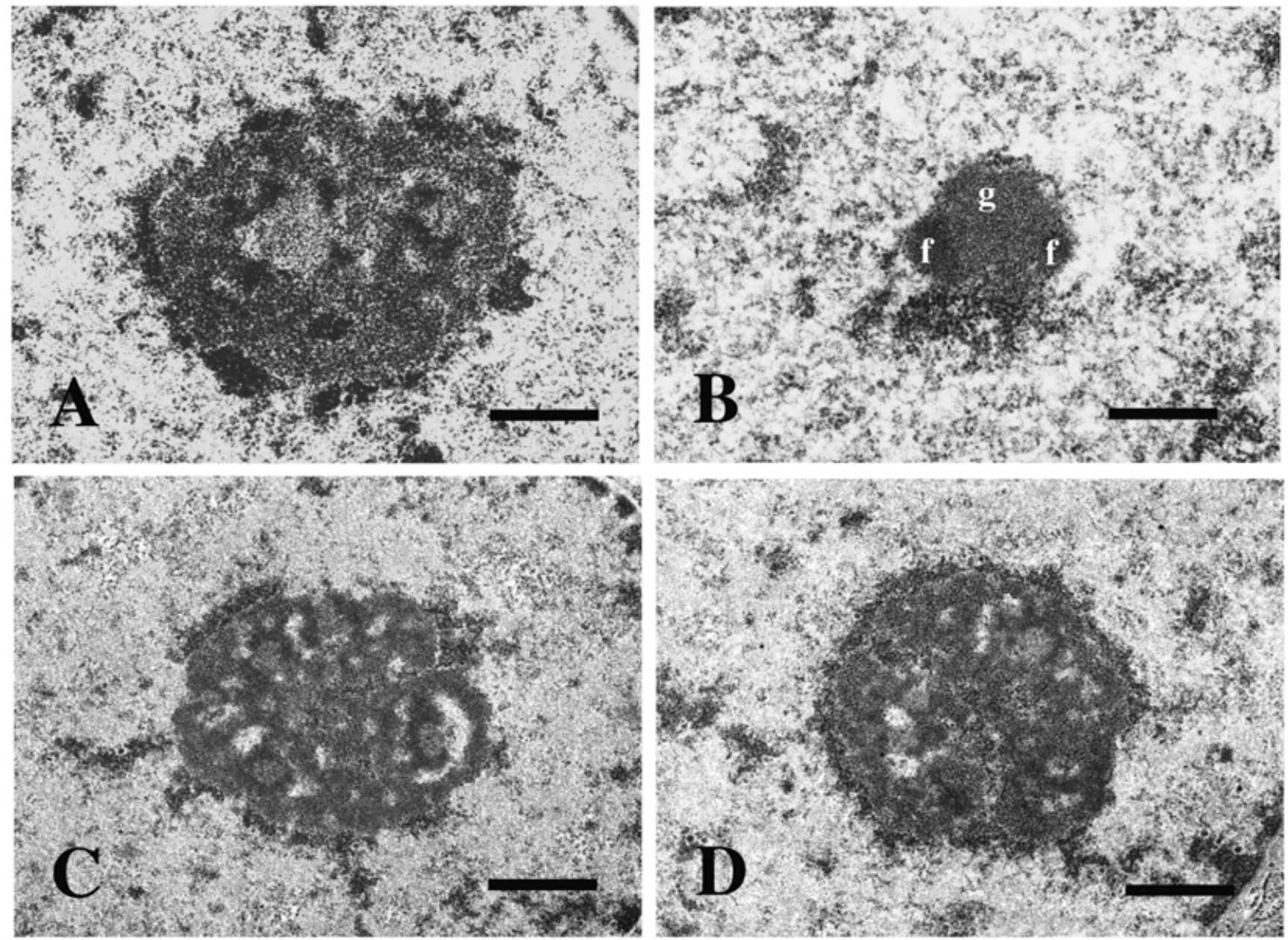

Fig. 3. Electron microscopy showing nucleolar segregation into granular (g) and fibrillar (f) zones in a colon epithelial cell nucleus of a rat $24 \mathrm{hr}$ after treatment with PhIP (B). Such nucleolar alterations are not seen in normal colon cells without PhIP exposure (A), nor in a hepatocyte without (C) or with (D) PhIP exposure. Bar $=500 \mathrm{~nm}$.

\section{Ultrastructural changes}

Nuclei of normal cells in control rats without PhIP treatment generally contained a single, irregularly contoured, nucleolus consisting of electron-dense granules, fibrils and amorphous material. These components were observed to be intimately intermingled forming a mesh of nucleolonemal strands in normal colon epithelium and liver cells of the vehicle-treated rats (Fig. 3A and 3C). In contrast, the most prominent ultrastructural change caused by the administration of PhIP was that of nucleoli which were clearly segregated into separate granular and fibrillar zones in cells of the colon epithelial cells (Fig. 3B), but not of the liver parenchymal cells (Fig. 3D). The results of the sequential investigation of the percentages of cells exhibiting nucleolar segregation in response to PhIP are summarized in Fig. 2B. Such nucleolar alteration was already noted $4 \mathrm{hr}$ after the administration of PhIP in colon epithelial cells, the rate being significantly $(P<0.05)$ increased $24 \mathrm{hr}$ after the carcinogen treatment. The highest percentages of cells with nucleolar segregation were about $16 \%$ in the colon epithelial cells, $48 \mathrm{hr}$ after the PhIP treatment, but the rate was less than $0.1 \%$ in the controls. At $72 \mathrm{hr}$ after PhIP administration, the rate of nucleolar alteration was still about $8 \%$. PhIP treatment thus caused an increase and/or accumulation of interchromatin and perichromatin granules in colonic epithelial cells. At later time points cytoplasmic organelles of cells with nucleolar segregation also appeared altered. In particular, the rough surfaced endoplasmic reticulum of colon epithelial cells became markedly dilated with depletion of membranebound and free ribosomes $6 \mathrm{hr}$ after administration of PhIP (data not shown). Thus, the target colon cells of PhIPtoxicity consistently showed both nucleolar segregation and DNA adduct formation.

\section{Cell proliferation activity}

Appreciable numbers of colon epithelial cells showed obvious stainability for PCNA in rats receiving PhIP (Fig. 4B), almost similar to control rats (Fig. 4A). However, more colon epithelial cells exhibited strong stainability for Ki-67 at $72 \mathrm{hr}$ after the $\mathrm{PhIP}$ treatment than those in control rats, in which positive rate was consistently low (Fig. 4E and 4F). 

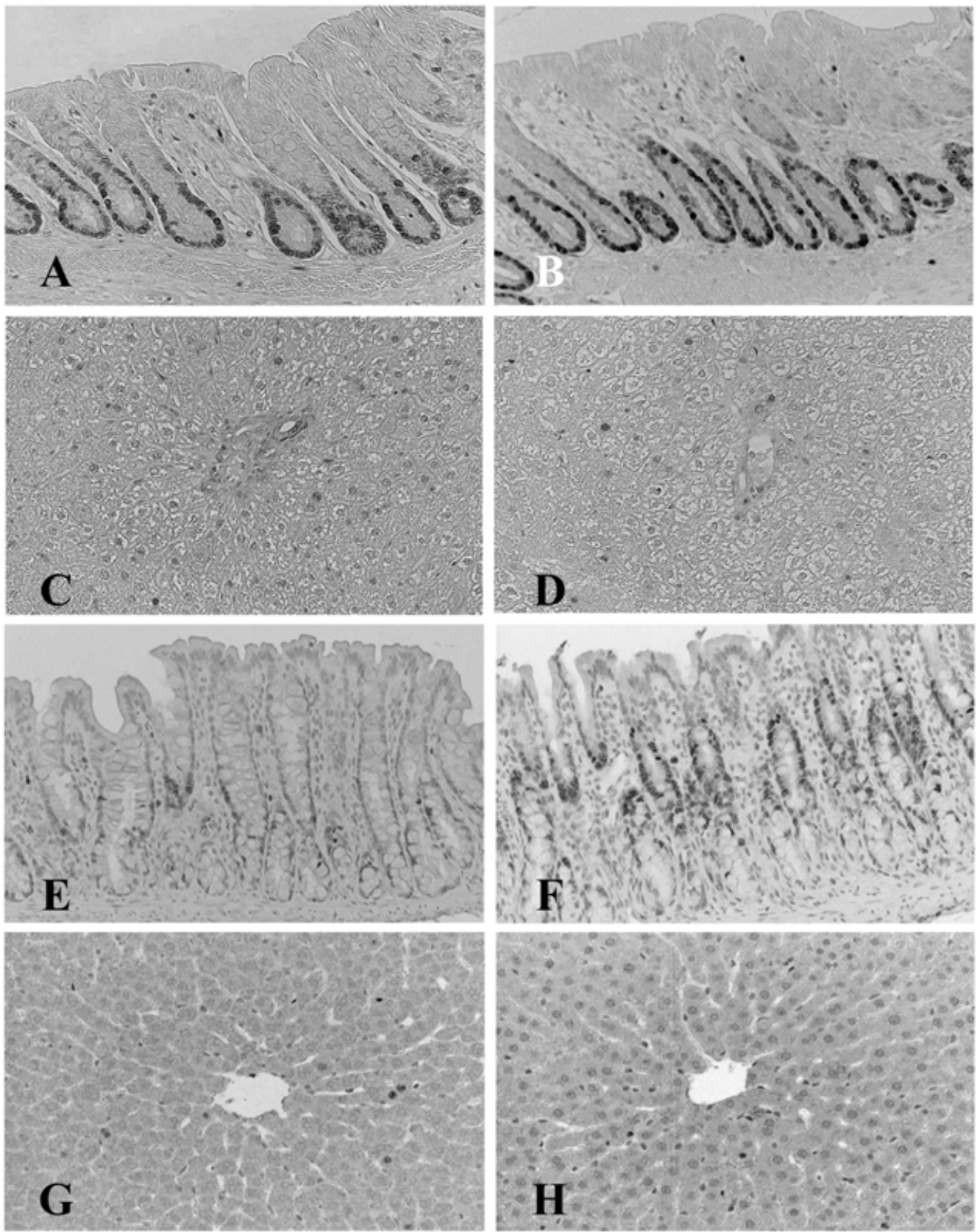

Fig. 4. Immunohistochemistry of PCNA (A-D) and Ki-67 (E-H) in the colons (A and $\mathbf{E})$ and livers $(\mathbf{C}$ and $\mathbf{G})$ from control rats, and colons $(\mathbf{B}$ and $\mathbf{F})$ and livers $(\mathbf{D}$ and $\mathbf{H})$ from rats $24 \mathrm{hr}$ after treatment with PhIP.

The cells positive for Ki-67 were more strictly localized than those for PCNA, reflecting their different capabilities for recognizing ranges of the cell cycle. In contrast, the nontarget hepatocytes from both control and PhIP-treated rats were scarcely positive for neither PCNA nor Ki-67 (Fig. 4C, $4 \mathrm{D}, 4 \mathrm{G}$ and $4 \mathrm{H})$. Thus, although no significant increase in PCNA-labeling was seen in colon epithelial cells of the PhIP-treated rats (Fig. 5B), Ki-67-labeling was significantly $(P<0.05)$ increased at $72 \mathrm{hr}$ after treatment, the value being about $12 \%$ (Fig. 6A). No increases in PCNA- or Ki-67labeling were noticed in hepatocytes regardless of PhIP exposure (Fig. 5C and 6B).

\section{Discussion}

The present investigation of sequential immunohistochemical staining using polyclonal antibodies against PhIP-DNA adducts between $4 \mathrm{hr}$ and $72 \mathrm{hr}$ after injection of PhIP to rats revealed that PhIP metabolites bind to DNA of the target colon epithelial cells but not of the nontarget hepatocytes. The precise localization of PhIP-DNA adducts at individual cell levels found in the present experiments supports the specificity of the anti-PhIP-DNA adduct antibody raised. Enzyme-linked immunosorbent and immunohistochemical assays have revealed a very high 
A

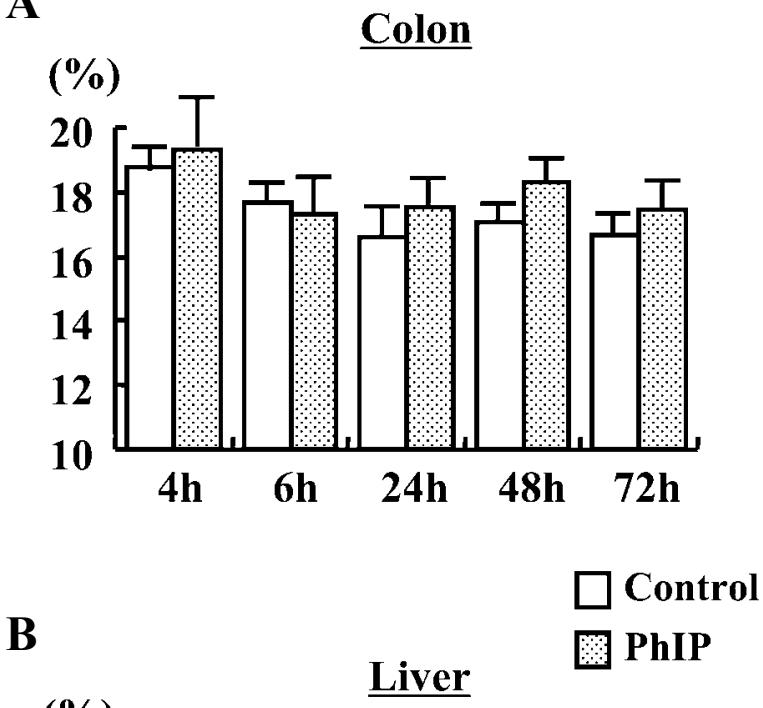

(\%)

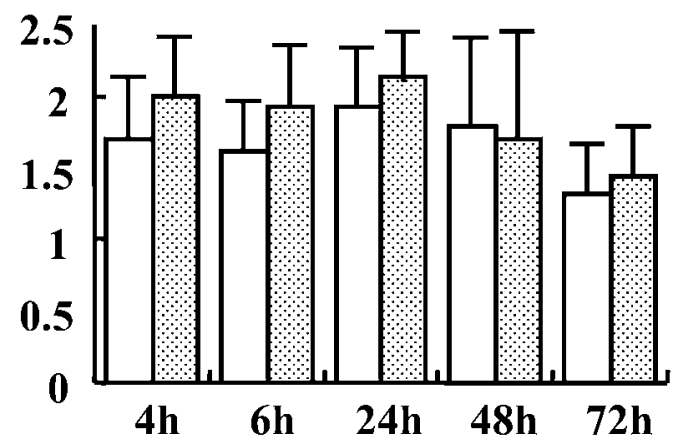

Fig. 5. Sequential changes of PCNA-labeling index in the colon (A) and liver (B) of rats treated with PhIP or vehicle alone. Data are mean \pm standard deviation values.

affinity to the antibody for PhIP-DNA adducts without cross-reactivity with unmodified DNA or other carcinogenmodified DNA adducts ${ }^{10}$. DNA modification through covalent binding of carcinogens is thought to be an essential step for the activity of genotoxic carcinogens ${ }^{22-25}$, but is not in itself enough to initiate carcinogenesis. In addition to possible formation of DNA adduct types that are not relevant to carcinogenesis, highly efficient DNA repair and subsequent inadequate fixation of heritable DNA lesions have also been suggested as complicating factors. Therefore, it has been shown that DNA adduct formation is a prerequisite, but is not of itself sufficient for carcinogenicity, and DNA adduct levels may correlate with carcinogenic responses only in target organs ${ }^{23,26}$. Thus, the immunohistochemical approach allows comparative morphological analysis as exemplified by the present documented clear positive correlation between PhIP-DNA adduct formation and nucleolar alterations, which were consistently observed only in the target organs of PhIPtoxicity. The absence of staining of PhIP-DNA adducts and no remarkable nucleolar changes in hepatocytes are in line with a non-target organ status, although the reason for the
A
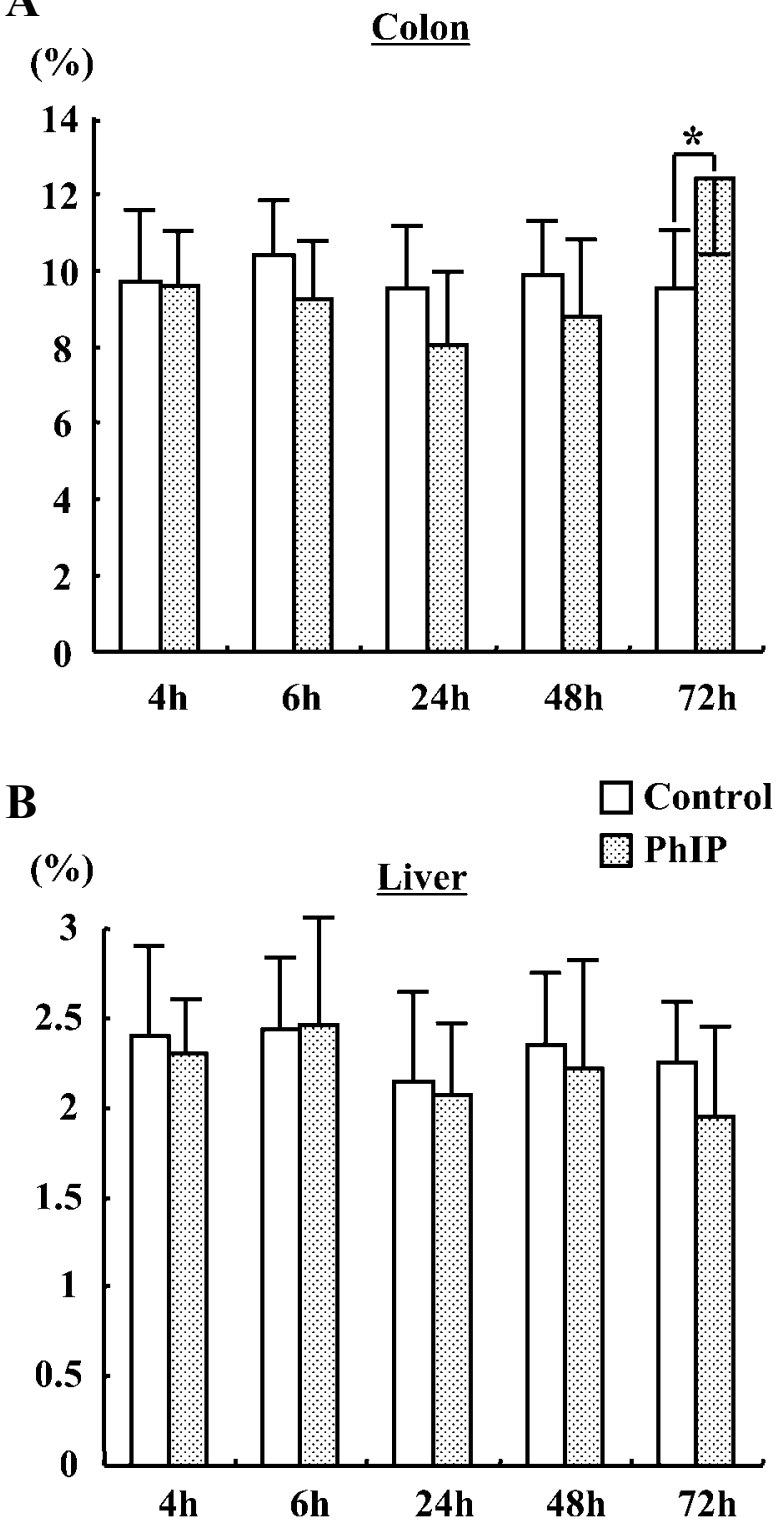

Fig. 6. Sequential changes of Ki-67-labeling index in the colon (A) and liver (B) of rats treated with PhIP or vehicle alone. Data are mean \pm standard deviation values. *Significantly different from the control group value at $P<0.05$ by Student's $t$-test; $\mathrm{n}=5$.

essentially negative PhIP-DNA binding in the liver is enigmatic since the liver is considered to be an active site of metabolism of this carcinogen ${ }^{27}$. Organ and species differences in metabolism of PhIP and repair of PhIP-DNA adduct formation could also play a role in negative PhIPDNA binding in the liver as reported previously ${ }^{27,28}$.

Sequential ultrastructural observation revealed nucleolar segregation of granular and fibrillar components as the most prominent alteration in the target colon epithelial cells, but not in the non-target liver cells in rats given PhIP. Such nucleolar alterations are known to occur in a variety of in vitro and in vivo cell systems following exposure to 
various compounds including actinomycin $\mathrm{D}^{29}, 4 \mathrm{HAQO}^{11}$, 4-nitroquinoline 1 -oxide ${ }^{30}$, aflatoxin $\mathrm{B}_{1}{ }^{31}$, amanitin ${ }^{32}$, proflavin $^{33}$ and adriamycin ${ }^{34,35}$. These compounds possess in common the biochemical property of forming complexes with DNA either by nucleophilic substitution of nucleoside residues or by intercalation between adjacent base pairs, thereby interfering with DNA-dependent ribosomal RNAsynthesis, the mechanism of which may be due to functional abnormality of the template DNA ${ }^{33}$. Reynolds et al. ${ }^{33}$ put forward the hypothesis that nucleolar segregation is an early morphological marker for a special type of cell injury involving DNA. Accordingly, nucleolar segregation is particularly indicative of toxic effects, but not directly of carcinogenic effects. PhIP-induced DNA damage may also be to the cause of the altered nucleolar morphology seen in the colon epithelium cells. Currently, the morphological description of apoptosis is characterized by segregation of the nucleolus ${ }^{36-41}$, although the fate of cells exhibiting nucleolar segregation remains to be investigated. It is likely that some of these cells readily give rise to apoptosis whereas others may reversibly recover from such alterations or lead to necrosis. In fact, apoptotic cells were occasionally found in the present study (data not shown). The results of the present study indicate that PhIP induces DNA adduct formation, and almost simultaneously or a little later brings about nucleolar segregation in the target organs of PhIP toxicity in rats. We therefore suggest that nucleolar segregation may have an application as a very early biomarker which predicts cellular injury involving DNA damage.

PCNA is closely involved in DNA replication and repair, in addition to increasing the efficiency of DNA synthesis. Most non-growing cells contain little PCNA mRNA and protein ${ }^{42}$, so that activated synthesis is necessary for the purpose of DNA repair after genotoxic insult in populations of non-growing cells. PCNA is well established as a useful marker for replication of $\mathrm{DNA}^{43}$. In the present study, PCNA-positive rates were not significantly elevated in colon epithelial cells of PhIP-treated rats as compared with control rats. However, the Ki-67 index was significantly increased $72 \mathrm{hr}$ after the carcinogen treatment, clearly indicating that cell proliferation activity was also elevated in colon epithelium cells. Since PCNA or Ki-67 expression is associated with cell proliferation as well as DNA synthesis and repair ${ }^{42,44}$, the immunohistochemical approach allowed comparative morphological analysis.

Segregation of nucleolar components into granular and fibrillar compartments was evident in the target colon cells but not in the non-target hepatocytes. As we have previously reported, DNA adduct formation and nucleolar alteration can be consistently demonstrated by immunohistochemical methods using antibodies directed against 4HAQO-DNA adducts and electron microscopy for segregation of nucleolar components in the target organs of rats given a single injection of $4 \mathrm{HAQO}^{11}$. In conclusion, the results of the present study indicate that DNA adducts, nucleolar alteration and enhanced cell replication are closely related phenomena involved in the early phase of PhIP-induced carcinogenesis following DNA damage, suggesting that these parameters are useful biomarkers for predicting the target organs of chemical carcinogenesis.

Acknowledgement: This work was supported in part by a Grant-in-Aid for Cancer Research from the Ministry of Health, Labour and Welfare of Japan.

\section{References}

1. Sugimura T. Studies on environmental chemical carcinogenesis in Japan. Science. 233: 312-318. 1986.

2. Falzon $\mathrm{M}, \mathrm{Vu} \mathrm{VT}$, Roller PP, and Thorgeirsson SS. Relationship between 7,12-dimethyl- and 7,8,12trimethylbenz $[a]$ anthracene DNA adduct formation in hematopoietic organs and leukemogenic effects. Cancer Lett. 37: 41-49. 1987.

3. Totsuka Y, Fukutome K, Takahashi M, Takahashi S, Tada A, Sugimura T, and Wakabayashi K. Presence of $N^{2}$ (deoxyguanosin-8-yl)-2-amino-3,8-dimethylimidazo[4,5$f$ ]quinoxaline (dG-C8-MeIQx) in human tissues. Carcinogenesis. 17: 1029-1034. 1996.

4. Layton DW, Bogen KT, Knize MG, Hatch FT, Johnson VM, and Felton JS. Cancer risk of heterocyclic amines in cooked foods: an analysis and implications for research. Carcinogenesis. 16: 39-52. 1995.

5. Ito N, Hasegawa R, Sano M, Tamano S, Esumi H, Takayama $\mathrm{S}$, and Sugimura $\mathrm{T}$. A new colon and mammary carcinogen in cooked food, 2-amino-1-methyl-6-phenylimidazo[4,5b]pyridine (PhIP). Carcinogenesis. 12: 1503-1506. 1991.

6. Shirai T, Cui L, Takahashi S, Futakuchi M, Asamoto M, Kato K, and Ito N. Carcinogenicity of 2-amino-1-methyl-6phenylimidazo $[4,5-b]$ pyridine (PhIP) in the rat prostate and induction of invasive carcinomas by subsequent treatment with testosterone propionate. Cancer Lett. 143: 217-221. 1999.

7. Hirose M, Yamaguchi T, Lin C, Kimoto N, Futakuchi M, Kono T, Nishibe S, and Shirai T. Effects of arctiin on PhIPinduced mammary, colon and pancreatic carcinogenesis in female Sprague-Dawley rats and MeIQx-induced hepatocarcinogenesis in male F344 rats. Cancer Lett. 155: 79-88. 2000.

8. Buonarati MH, Turteltaub KW, Shen NH, and Felton JS. Role of sulfation and acetylation in the activation of 2hydroxyamino-1-methyl-6-phenylimidazo[4,5-b]pyridine to intermediates which bind DNA. Mutat Res. 245: 185-190. 1990.

9. Frandsen H, Grivas S, Andersson R, Dragsted L, and Larsen JC. Reaction of the $N^{2}$-acetoxy derivative of 2-amino-1methyl-6-phenylimidazo[4,5-b]pyridine (PhIP) with 2'deoxyguanosine and DNA: synthesis and identification of $N^{2}$-(2'-deoxyguanosin-8-yl)-PhIP. Carcinogenesis. 13: 629635. 1992.

10. Takahashi S, Tamano S, Hirose M, Kimoto N, Ikeda Y, Sakakibara M, Tada M, Kadlubar FF, Ito N, and Shirai T. Immunohistochemical demonstration of carcinogen-DNA adducts in tissues of rats given 2-amino-1-methyl-6phenylimidazo[4,5-b]pyridine (PhIP): detection in paraffinembedded sections and tissue distribution. Cancer Res. 58: 4307-4313. 1998. 
11. Imazawa $T$, Nishikawa $A$, Tada $M$, Takahashi $M$, and Hayashi Y. Nucleolar segregation as an early marker for DNA damage; an experimental study in rats treated with 4hydroxyaminoquinoline 1-oxide. Virchows Arch. 426: 295300. 1995.

12. Imazawa $\mathrm{T}$, Nishikawa A, Toyoda K, Furukawa F, Mitsui $\mathrm{M}$, and Hirose M. Sequential alteration of apoptosis, $p 53$ expression, and cell proliferation in the rat pancreas treated with 4-hydroxyaminoquinoline 1-oxide. Toxicol Pathol. 31: 625-631. 2003.

13. Morishita R, Gibbons GH, Ellison KE, Nakajima M, Zhang L, Kaneda Y, Ogihara T, and Dzau VJ. Single intraluminal delivery of antisense cdc2 kinase and proliferating-cell nuclear antigen oligonucleotides results in chronic inhibition of neointimal hyperplasia. Proc Natl Acad Sci USA. 90: 8474-8478. 1993

14. Zhang G, Gibbs E, Kelman Z, O'Donnell M, and Hurwitz J. Studies on the interactions between human replication factor $\mathrm{C}$ and human proliferating cell nuclear antigen. Proc Natl Acad Sci USA. 96: 1869-1874. 1999.

15. Stivala LA, Riva F, Cazzalini O, Savio M, and Prosperi E. p21(waf1/cip1)-null human fibroblasts are deficient in nucleotide excision repair downstream the recruitment of PCNA to DNA repair sites. Oncogene. 20: 563-570. 2001.

16. Gruz P, Pisani FM, Shimizu M, Yamada M, Hayashi I, Morikawa K, and Nohmi T. Synthetic activity of Sso DNA polymerase $\mathrm{Y} 1$, an archaeal DinB-like DNA polymerase, is stimulated by processivity factors proliferating cell nuclear antigen and replication factor C. J Biol Chem. 276: 47394 47401. 2001.

17. Maga G, Villani G, Ramadan K, Shevelev I, Tanguy Le Gac N, Blanco L, Blanca G, Spadari S, and Hubscher U. Human DNA polymerase lambda functionally and physically interacts with proliferating cell nuclear antigen in normal and translesion DNA synthesis. J Biol Chem. 277: 4843448440. 2002.

18. Haracska L, Acharya N, Unk I, Johnson RE, Hurwitz J, Prakash L, and Prakash S. A single domain in human DNA polymerase iota mediates interaction with PCNA: implications for translesion DNA synthesis. Mol Cell Biol. 25: $1183-1190.2005$.

19. Doolittle DJ, McKarns SC, Ayres PH, and Bombick DW. Molecular approaches for quantifying DNA synthesis and cell proliferation during rodent bioassays. Toxicol Methods. 1: 215-230. 1992.

20. Gerdes J, Lemke H, Baisch H, Wacker HH, Schwab U, and Stein H. Cell cycle analysis of a cell proliferation-associated human nuclear antigen defined by the monoclonal antibody Ki-67. J Immunol. 133: 1710-1715. 1984.

21. Shi SR, Key ME, and Kalra KL. Antigen retrieval in formalin-fixed, paraffin-embedded tissues: an enhancement method for immunohistochemical staining based on microwave oven heating of tissue sections. J Histochem Cytochem. 39: 741-748. 1991.

22. Miller EC. Some current perspectives on chemical carcinogenesis in humans and experimental animals: Presidential address. Cancer Res. 38: 1479-1496. 1978.

23. Shirai T, Tada M, Kojima M, Hasegawa R, Masui T, and Ito N. DNA adducts in target and nontarget tissues of 3,2'dimethyl-4-aminobiphenyl in rats. Environ Health Perspect. 102: 167-172. 1994.

24. Cohen SM and Ellwein LB. Relationship of DNA adducts derived from 2-acetylaminofluorene to cell proliferation and the induction of rodent liver and bladder tumors. Toxicol Pathol. 23: 136-142. 1995.

25. Barbin A. Role of etheno DNA adducts in carcinogenesis induced by vinyl chloride in rats. IARC Sci Publ (Lyon). 303-313. 1999.

26. Shirai T, Fukushima S, Kawabe M, Shibata MA, Iwasaki S, Tada M, and Ito N. Selective induction of rat urinary bladder tumors by simultaneous administration of 3,2'-dimethyl-4aminobiphenyl (DMAB) and butylated hydroxyanisole or butylated hydroxytoluene is associated with increased DMAB-DNA adduct formation. Carcinogenesis. 12: 13351339. 1991.

27. Lin DX, Lang NP, and Kadlubar FF. Species differences in the biotransformation of the food-borne carcinogen 2amino-1-methyl-6-phenylimidazo[4,5- $b$ ]pyridine by hepatic microsomes and cytosols from humans, rats, and mice. Drug Metab Dispos. 23: 518-524. 1995.

28. Snyderwine EG, Yu M, Schut HA, Knight-Jones L, and Kimura S. Effect of CYP1A2 deficiency on heterocyclic amine DNA adduct levels in mice. Food Chem Toxicol. 40: 1529-1533. 2002.

29. Reynolds RC, Montgomery PO, and Hughes B. Nucleolar "caps" produced by actinomycin D. Cancer Res. 24: 12691277. 1964

30. Hayashi $\mathrm{Y}$ and Hasegawa T. Nucleolar alterations of alveolar epithelial cells in rats following a single injection of 4-nitroquinoline 1-oxide. Gann. 61: 347-352. 1970.

31. Svoboda D, Racela A, and Higginson J. Variations in ultrastructural nuclear changes in hepatocarcinogenesis. Biochem Pharmacol. 16: 651-657. 1967.

32. Kisilevsky R. Hepatic nuclear and nucleolar changes in Amanita poisoning. Arch Pathol. 97: 253-258. 1974.

33. Reynolds RC and Montgomery PO. Nucleolar pathology produced by acridine orange and proflavine. Am J Pathol. 51: 323-339. 1967.

34. Merski JA, Daskal I, and Busch H. Effects of adriamycin on ultrastructure of nucleoli in the heart and liver cells of the rat. Cancer Res. 36: 1580-1584. 1976.

35. Hayashi $Y$, Imazawa $T$, Kokubo $T$, Kurokawa $Y$, and Takahashi M. Nucleolar alterations of myocardial cells and glomerular epithelial cells in rats after a single administration of adriamycin. Toxicol Lett. 20: 105-110. 1984.

36. Seegers JC, Bohmer LH, Kruger MC, Lottering ML, and de Kock M. A comparative study of ochratoxin A-induced apoptosis in hamster kidney and HeLa cells. Toxicol Appl Pharmacol. 129: 1-11. 1994.

37. Reipert S, Bennion G, Hickman JA, and Allen TD. Nucleolar segregation during apoptosis of haemopoietic stem cell line FDCP-Mix. Cell Death Differ. 6: 334-341. 1999.

38. Halicka HD, Bedner E, and Darzynkiewicz Z. Segregation of RNA and separate packaging of DNA and RNA in apoptotic bodies during apoptosis. Exp Cell Res. 260: 248256. 2000.

39. Horky M, Wurzer G, Kotala V, Anton M, Vojtesek B, Vacha J, and Wesierska-Gadek J. Segregation of nucleolar components coincides with caspase- 3 activation in cisplatintreated HeLa cells. J Cell Sci. 114: 663-670. 2001.

40. Miller ML, Andringa A, Dixon K, and Carty MP. Insights into UV-induced apoptosis: ultrastructure, trichrome stain 
and spectral imaging. Micron. 33: 157-166. 2002.

41. Fraschini A, Bottone MG, Scovassi AI, Denegri M, Risueno MC, Testillano PS, Martin TE, Biggiogera M, and Pellicciari C. Changes in extranucleolar transcription during actinomycin D-induced apoptosis. Histol Histopathol. 20: 107-117. 2005.

42. Kelman Z. PCNA: structure, functions and interactions. Oncogene. 14: 629-640. 1997.
43. van Dierendonck JH, Wijsman JH, Keijzer R, van de Velde $\mathrm{CJH}$, and Cornelisse CJ. Cell-cycle-related staining patterns of anti-proliferating cell nuclear antigen monoclonal antibodies. Am J Pathol. 138: 1165-1172. 1991.

44. Toschi L and Bravo R. Changes in cyclin/proliferating cell nuclear antigen distribution during DNA repair synthesis. J Cell Biol. 107: 1623-1628. 1988. 